FACTA UNIVERSITATIS

Series: Philosophy, Sociology, Psychology and History Vol. 19, No 2, 2020, pp. 165 - 177

https://doi.org/10.22190/FUPSPH2002165K

Review Paper

\title{
TRAVEL CULTURE IN YUGOSLAVIA: AN ANALYSIS OF TOURISM PROPAGANDA
}

\author{
UDC 338.48:659.11(497.1)
}

\author{
Živana Krejić, Jelena Palić \\ University UNION - Nikola Tesla, Faculty of Business Studies and Law, \\ Belgrade, Serbia
}

\begin{abstract}
The paper is an overview on Yugoslav seaside tourism propaganda and mass tourism of the working class. The analysis is based on the archival material analyzed so far in the field of the history of tourism development and published scientific papers related to travel culture in Yugoslavia. The research aims to look at and analyze the tourist propaganda in Yugoslavia during the $20^{\text {th }}$ century from a sociological aspect, when one of the main characteristics of tourism was its mass occurrence. Despite the development of the economy and the rise of tourism, the citizens of Yugoslavia had a short vacation, during which they went to the sea, spas, mountains, most often making their own travel plans, and used the services of travel agencies the least. Numerous catalogs, brochures, newspaper advertisements represent important segments of tourist propaganda and a signpost for domestic tourists to popular destinations. The difficult position of workers who struggled to preserve the idea of going on vacation was also visible through some of the slogans about summer vacations: "Those who have money bathe in the sea, and those who do not have money bathe at home in the washbowl." The standard of living of the people dictated their decisions about travel, and only in 1964 was the decision made that the annual vacation should last for six days and be paid, which gave tourism the epithet of social tourism. The results of the overview provide insight into the everyday life of the inhabitants of Yugoslavia, their possibilities for going on vacation, tourist propaganda which was very lavish in its beginnings, but also the most common destinations they travelled to.
\end{abstract}

Key words: tourism, travel, culture, workers, everyday life, Yugoslavia.

\section{INTRODUCTION}

The beginnings of the development of tourism in today's Serbia should be sought between the establishment of the Vrnjci Medicinal Mineral Hot Water Founding Society in July 1868, the construction of the Belgrade-Niš railway in 1884, and the mid-1890s when the organization of excursions in the vicinity of Belgrade became common (by train

Received June 13, 2020 / Accepted July 18, 2020

Corresponding author: Živana Krejić

University UNION - Nikola Tesla, Faculty of Business Studies and Law, Jurija Gagarina 149a, Belgrade, Serbia

E-mail: zkrejic@yahoo.com 
to Rakovica, Kneževac, Resnik; by rented boat to Kostolac, Gradište, Umka, Obrenovac, Smederevo, Zemun, Pančevo). By the beginning of the First World War, the most famous forms of tourism were developed and are still present, such as: organized trips to world fairs and exhibitions (Paris 1900, London 1907); the departure of Belgraders to the sea (in the $19^{\text {th }}$ century the most common destination was Abacija, today's Opatija) and spas, where the construction of permanent holiday homes began; group trips to Slavic countries. At the turn of the $19^{\text {th }}$ and $20^{\text {th }}$ centuries, the first foreign tourists arrived in Belgrade, mainly on their way to the Orient (Lazić 2015; Krejić \& Milićević 2019).

The industrial revolution, the advent of the steam engine, and the development of the railroad provided people with greater opportunities for movement and travel. In the second half of the $19^{\text {th }}$ century, the vacation of the local population was directed towards staying in nature and traveling and excursions for wealthier citizens. In their free time, the city population went on nature trips, far from the city. Many merchants and craftsmen had farms, whose original purpose was economic (Fotić 2005). All movements of the population were facilitated by the development of the steamship, railway and road transport network, whose development marked the entire $19^{\text {th }}$ century. Until then, only wealthy members of the city society traveled by mail carriages, stagecoaches, and horses, while poor citizens walked and crossed long distances, counting on the alms and hospitality of the peasants, mainly for treatment and pilgrimage (Popović \& Ozer 2015).

Although its roots go back to the eighteenth century, travel was still a novelty for the masses, and the homogeneous character of the demand led to the production of standardized products that could suit everyone (Sezgin \& Yolal 2012). In the $19^{\text {th }}$ century, in addition to hats and sticks, every tourist had to have a means of transportation. The development of traffic was a strong stimulus to the development of tourism, and travel became available to many (Malović 2013).

In the early years of the twentieth century, tourism continued to expand as a consequence of increasing wealth, interest and outgoing attitudes, and improvements in people's transport. Advances in transport allowed people to travel in masses. In fact, mass production and mass consumption was the rationale of that period. The first tourists in Yugoslavia visited the sea shores, mountains and spas, where, full of romantic enthusiasm, they admired the landscape (Duda 2008).

After the First World War, a period of post-war renewal and construction of the country began in Yugoslavia, which marked the most favorable events that would follow after the Second World War, such as the construction of new buildings, communal infrastructure, arrangement of squares, streets, etc. (Krejić \& Milićević 2018).

From the 1930s onwards, the growing availability of the motor car stimulated tourism further, and during the interwar years the aircraft began to play a small role in the tourism market as an option for the wealthier classes, particularly in Europe (Swarbrooke \& Horner 2007). Domestic tourists mostly traveled in three main directions: southern Serbia, Slovenia, the Adriatic Sea, while foreign tourists preferred to visit spas in Serbia, primarily Vrnjačka Banja. They mostly travelled by train, regular or special trains, mostly from Graz and Vienna, but also Plzen and Prague (Krejić \& Milićević 2018).

After the Second World War, Yugoslav communists gave little thought to the reconstruction of the tourism sector. The Yugoslav government changed its stance around 1950 when the country sought to re-establish links with foreign travel agencies. Although economic policy favored the development of heavy industry, tourism enterprises also vied for funding in what was the country' prime tourism region. As a Mediteranean holiday 
destination catering to low-income tourists, Yugoslavia benefited from the European boom in mass tourism in the 1950s and 1960s (Grandits \& Taylor 2010). The way seaside architecture developed after the Second World War under the pressure of mass tourism placed the socialist countries in a better position to fulfil the needs of mass tourism (Popescu 2015).

Consumer culture became an important part of the program of the League of Communists of Yugoslavia. A worker who has worked more will be able to afford products and services that will make him happy and satisfied. He will thus create better living conditions for himself and increase his standard. The most important condition for the working class to go on vacation was fulfilled by the enactment of legislation in 1946, according to which all employees after eleven months of work were entitled to fourteen days of vacation, with the receipt of a regular salary (Duda 2010). In this way, tourism became accessible to the working class.

One of the main features of the 20th century is the mass media, which had a great influence on the changes in human society. The press, radio and television gradually entered everyday life and had a great impact on people's lives (Popović \& Ozer 2015).

Mass media are an influential and widespread way of communication. Media technologies are used as intermediaries in mass communication addressed to a mass audience. Mass media include both traditional and new media: print, radio, television, film, digital media. Mass media have developed in the context of mass production, as intermediaries in directing and managing the processes of production and consumption. Their development has created a wide field of action and conditions for the development of a mass media culture that influences the production of everyday life and shapes social behavior. The mass media is an extension of the human body and human senses, in the process of exchanging information (Marshall McLuhan 1964; Sorlin 1994; Hall 2003).

The development of tourism was influenced by the development of the media, which in a short time recorded a revolutionary development. The role of mass media (TV, radio, newspapers, magazines) is focusing, in most cases, on a national or local territory. The mass media have an important social and political role in the formation of public opinion (Lemos 2010). Tourist propaganda is almost inseparable from tourism. Tourist propaganda in the Kingdom of Yugoslavia (SCS) developed after the First World War in parallel with the strengthening of tourism as one of the most important economic branches. At the end of the war, the aim was to rebuild the country and enable the recovery of injured people. In the period from 1920 to 1930 there were important changes in various fields related to the development of tourism: strengthening infrastructure, road construction and traffic development, arranging beaches, building infrastructure in spas, building hotels, developing travel agencies, organized action to improve and develop tourism and conquer the domestic and international market. This also influenced the development of tourist propaganda, which resulted in a larger number of domestic and foreign tourists (Vukonić 2005).

In the period between the two wars, tourism in Yugoslavia was experiencing its golden age. One of the main reasons for this was the opening of the first tourist agency in Yugoslavia. In 1923, a joint stock company for passenger and tourist traffic in the Kingdom of Serbs, Croats and Slovenians was established with its headquarters in Belgrade. This is how the first travel agency Putnik was created, as a company for passenger and tourist traffic (Krejić \& Milićević 2018). Putnik had numerous representative offices in the country and abroad. The main tasks of Putnik were aimed at informing tourists, organizing excursions, forming itineraries, selling tickets for various means of transport, tickets for cultural events, taking care of hotel accommodation, passenger insurance, obtaining visas 
and the like. Putnik also paid great attention to propaganda activities and the way in which the image of Yugoslavia was created for the domestic and foreign public. In order to produce the best and highest quality promotional materials, directors, cameramen, photographers, painters, and graphic designers were hired, whose task was to make the best possible tourist brochures, posters, and then promotional films. The catering and tourist offer was placed by publishing newspaper articles, through advertisements, leaflets, and with the appearance of radio and television, as mass communicators, the world became smaller and smaller (Vukonić 1973).

The aim of the paper is to analyze the available archival documents pertaining to the history of tourism development (posters, brochures, records, newspaper articles from the past) and scientific works in order to investigate advertising in Yugoslavia. This includes the messages of tourist propaganda, how free time was spent, using vacation days, and the destinations to which Yugoslavs gladly went, all of which was part of their lives.

Propaganda messages are aimed at the psyche and emotion of individual consumers, as future users of a particular good or service. Therefore, tourist advertising uses psychological aspects, individual and collective in nature, which are related to the prospects of tourist places and the excitement they produce in a potential client. On the other hand, the analysis of propaganda material reveals the state of and needs in society, its development, progress, but also culture (Šuran, 2016; Otić, Marković \& Grlica, 2012).

\section{The Cult of the VACATION AND THE BEgINNING OF MASS TRAVEL}

Before the founding of the socialist state, only the upper and middle classes of educated professionals, craftsmen and merchants traveled in Yugoslavia (Pilar 2016). Going on trips and parties in nature, in "houses for enjoyment", summer houses, was the prerogative of wealthy citizens who took with them housekeepers, who brought food and drinks for that purpose. The same strata of the population went on summer and winter vacations, to spas throughout Europe, for treatment and rehabilitation. Most vacationers were domestic guests, and most foreign guests were from Germany, Czechoslovakia, Hungary, Italy, Britain and Austria (Krejić \& Milićević 2018).

The beginning of mass of travel directed tourists from the Kingdom of Yugoslavia to visit thermal resorts, while foreign visitors usually spent their holidays in the coastal areas. Furthermore, in 1923 tourists from Czechoslovakia accounted for $81 \%$ of the total arrivals in the areas of Dubrovnik, Župa Dubrovačka, Rijeka Dubrovačka and Koločep. The percentage of Czechoslovakian tourists dropped to 54\% in 1924 and 30\% in 1925 . Over the same period the total arrivals of tourists from Austria rose from $3 \%$ to $13 \%$ and then to $19 \%$ respectively, while the arrivals of German tourists rose from 3\% in 1923 to $11 \%$ in 1924 and finally to $15 \%$ in 1925 (Penava Benić \& Matušić 2012, 62).

According to our research, tourism development in Dubrovnik is characterized by an almost two-fold increase in accommodation resources, more than a two-fold increase in tourist flow, and a ten-fold increase in the number of international tourists between 1925 and 1938.

Domestic tourism in Yugoslavia in the period after the Second World War took place in different social and economic conditions, and it also had different characteristics, but overall a significant upward trend. In the seventies, tourism gained the status of a priority, and numerous facilities were built, propaganda was improved and stimulating measures 
were introduced at the level of the federation (Stankovic 1989). Yugoslavia was visited annually by about 900,000 tourists who spent about five million nights there (Statistical Office of the Republic of Serbia 1960).

Among the local population, the middle and upper classes traveled for vacation, while the rest of the population visited picnic areas and freshwater beaches in the places of their permanent residence. The sunlit body, in the twenties, became a symbol of health, wellbeing and prestige. However, bathing in public and wearing bathing suits was not gladly accepted by the older generations. The new approach applied by socialist Yugoslavia with the introduction of paid annual leave and social tourism was important for the popularization of tourism (Helsinki Committee for Human Rights in Serbia 2017). The interference of the state and trade unions in the field of vacations and social tourism was not a Yugoslav invention or specialty. Concerns about the free time of workers were present in the $19^{\text {th }}$ century, and countries in Europe have been dealing with this issue since the beginning of the $20^{\text {th }}$ century, but it was only in 1930 that the issue received serious consideration. France went a step further and already in 1936 gave workers the right to a two-day vacation). In July 1946, the Yugoslav government decided to introduce a two-day paid annual leave, with regular salary for all workers who had been working for eleven months (Duda 2005). The general right of workers to annual leave lasting two to four days was introduced in 1946. However, the real turning point came only after the Second World War, especially in the 1960s, when "citizens understood paid vacation as their right" (Rusac 2014). "These legal provisions, together with the expanded European understanding that no one should spend a holiday at home, as well as the Yugoslav standard of living and economic development, created an excellent environment for social tourism" (Škara 2016, 13). This system had two pillars: the first were cash benefits and holiday pay, and the second were accommodation facilities, namely workers' resorts or homes (Duda 2013). In the middle of the summer of 1946, at a rally in Split, Josip Broz Tito, the Prime Minister of the Federal People's Republic of Yugoslavia at the time, evaluating the post-war successes in settling the situation presented his ideas on the role of the Adriatic coast in shaping a more successful society: "I saw that efforts have been made in Dalmatia in terms of hygiene and health, and I must say that what was done was good and that it was done quite well. But all that is still small, according to what needs to be done. The beautiful coast of our Dalmatia can provide opportunities for strengthening the health of the working masses of all people of the Federal People's Republic of Yugoslavia. We need to create convalescent homes and sanatoriums from the beautiful Dalmatian coast, so that everyone who works and contributes to the community can come to improve their health and then start working even harder again" (Tito 1946; Taken from Magazine Luftika, author's translation). A year later, the Federal Government issued an order on the benefits for union members on vacation - the famous 'K-15' and 'holiday pay'. In socialism, these were exactly the privileges of every employee - to receive special discounts for travel and accommodation at the seaside, and to also receive pocket money from their employer for summer vacations. Unions and resorts were struggling to motivate workers to travel in the late 1940s and early 1950s which was what the first workers' tourism on the Croatian coast looked like. Even if they managed to force them to go on vacation, the workers had no idea how to behave in the resorts, and they often caused problems. In the Croatian State Archives, the documents testify that the problem in the resorts was often the incompetence of the staff and the abuse of the manager, but also poor equipment and food. All this would sometimes end in a premature return home. Like everything else, the equipment of the resort was prescribed by ideal standards, but the reality was often quite 
different (Duda 2011; Anonymus 2019). Going on vacation is understood as an indispensable part of the standard of living and as a right of the entire population. The system of social tourism introduces preferential prices for accommodation and transport, holiday pay. Workers', children's and youth resorts were established. Despite some objections, many workers were satisfied: "Workers' resorts are cheaper and people feel freer. Besides, everything is organized, so we don't have to worry about anything. That is how a pleasant and really carefree vacation was spent"; "Apart from the blue sky, what do you really need for a vacation?" (Ilić 2018; Župančić \& Puljić 2016, 245, author's translation). Many traveled for the first time in the middle of the $20^{\text {th }}$ century and saw the sea, which was the main destination for summer vacations. Admiration for the sea was common in entertainment melodies and media that regularly reported on the holidays of workers, but also domestic film, music and sports stars. "My favorite encounter is with our blue shores of the Adriatic, and I like it best when I swim in it," (Župančić \& Puljić 2016, 243, author's translation) is one of the many similar statements transmitted by the local press at the time. With large investments, tourism recorded a rapid rise until a record in 1986, with more than 111 million overnight stays, among which foreign and domestic guests from West Germany, Serbia, Slovenia, Croatia, Bosnia and Herzegovina, Great Britain, Austria and Italy were represented (Statistical office of the Republic of Serbia, Statistički godišnjak 1986). Surveys showed that in late socialism, every second citizen traveled during the holidays, mostly smaller families, better educated and with higher incomes, and a permanent address in larger cities in the interior of the country. Commercial and international tourism strengthened during the $1960 \mathrm{~s}$, when the country opened up to the West and the importance of foreign exchange earnings from tourism was recognized. The growth of private accommodation and more and more family houses with the inscription "Zimmer frei", indicating the orientation to German-speaking tourist markets, were one of the signs of changes that tourism brought to the local population, especially in the Adriatic and mostly in Croatia, which was the most sought after tourist destination in Yugoslavia. Foreign guests brought the hosts closer to the modern West with their consumer goods, behavior and habits, while well-kept beaches, sports fields, swimming pools, hotel restaurants and congress halls found their public year-round purpose. Unlike annual leave, the weekend had to wait for its full role until 1965, when the working week was shortened by law to 42 working hours, which for most jobs meant five eight-hour working days and one working Saturday per month. In 1967, every fifth citizen of Zagreb went on a half-day or fullday trip, while in the early 1980s every third Yugoslav at least sometimes went on weekend trips. They were most often forced to stay at home due to lack of money, then lack of time or underdevelopment of habits and the need for such spending of free time. Weekends are inevitably associated with weekend cottages, whose construction began in the 1950s, and by the 1980s had spread to different segments of the population. They were most often built in the vicinity of large cities and industrial centers where they really served for a short weekly rest, going out into the fresh air and preparing a barbecue. In the summer, it was important for many to own a cottage by the sea: "We are here on our "own place"; it is simply different to be a tourist" (Helsinki Committee for Human Rights in Serbia 2017).

As Duda (2005) points out, travel had a dual role: on the one hand, it contributed to the creation of happy citizens who may have left their homeland for the first time to visit a more or less distant destination and enjoy the illusion of a different life. On the other hand, touring the homeland, especially in crucial historical periods, raised national (or supranational) awareness, enabling the acquaintance of compatriots and the homogenization of the community. 


\section{The BEgINNING OF TOURIST PROPAGANDA IN YUGOSLAVIA}

The first forms of spreading certain ideas in terms of propaganda can be found in ancient times. However, it was not until the $17^{\text {th }}$ century that the term "propaganda" came into being. The name propaganda is related to the Latin verb "propare", which means spreading or reproducing. During 1622, on the basis of an order of Gregory XV, a special organization for the spread of the faith was founded. It was called "Sacra Congregatio De Propagande Fide", and was later abbreviated as "propaganda". This expression is of an older date, and propaganda in the modern sense of the word is a phenomenon of more recent times and was in wider use between the two world wars, especially in the period after the Second World War. Propaganda originates with the emergence of commodity production and its development path is observed with the development of this form of production. Propaganda is used in various forms of social phenomena and relations, in order to spread various types of political, cultural, ideological, educational, humanitarian and various other ideas, or in the economic field, in order to achieve certain economic results. It is used in both economic and non-economic fields (Mitrović 1988).

Advertising has changed and adapted to the needs of business and social life during general historical development. Therefore, it is a very important and valuable source for studying the economy, history, culture, but also everyday life. Its significance was understood in the distant past by merchants and craftsmen, but advertising as a modern propaganda tool, with a well-worded text and a pleasing artistic solution or image, it said to have started from the middle of the $19^{\text {th }}$ century (Otić, Marković \& Grlica 2012). According to Jean Meynaud (1964), advertising is a form of capitalist propaganda and consumer exploitation. It is in the hands of large companies and it serves to make them as much profit as possible. Regardless of the type of advertising, the preserved advertising materials represent a list of economic entities of the past. Advertisements in the form of company signs, boards, leaflets, posters, memoranda, catalogs, guides represent the most common forms of advertising (Garić 2010).

The oldest tourist guide about Belgrade, with the exception of several foreign publications which, among other things, wrote about the sights of the Orient and included the Serbian capital, was written in 1896 (Lazić 2015). The first posters and brochures that appeared in Yugoslavia were related to catering facilities: taverns, cafes, pubs, hotels and the need to advertise in this way (Otić, Marković \& Grlica 2012). The importance of advertising and the possibility of earning from advertising was soon realized by the authorities, which, within the Statute on the regulation of advertising, precisely defined the places for placing advertisements, and those were pillars, pavilions and boards. Placing advertisements on houses, fences, buildings and candelabra was prohibited. Advertising jobs were entrusted to certain advertising city institutes, such as the Institute for Advertising and Poster Posing in Novi Sad, "Bošnjaković and Radić". In one of the letters from 1926, it is requested that the posters sent to Pančevo remain visible for 30 days (Historical Archive of Novi Sad 1926).

By analyzing the material related to the Adriatic coast which in the past was a favorite of many foreign tourists, but also a favorite travel destination of Yugoslavs, an important role in propaganda campaigns and promotion of the coast during the 1920s was played by the Split Association for Tourism Promotion which was joined by the Split, Dubrovnik and Sušak federations. Individual associations and representative offices of Putnik acted independently in relation to the Belgrade representative office that co-financed them, and the natural beauties and wealth of the Kingdom of Yugoslavia were presented in various 
ways - by issuing postcards, photographs, posters, and brochures, on the radio or with slides (Vukonić 1973). Published by the Adriatic Guard, Crnjanski also wrote about the Adriatic coast in 1927 and about the Bay of Kotor in 1928. In the period between the two world wars, a new guide was published every few years, and among them a particularly interesting guide was prepared by the great writer Miloš Crnjanski, printed in 1936 in French (Crnjanski 1936).

An important role in popularizing various tourist destinations and promoting visits to the Adriatic and other parts of Yugoslavia was played by regular placement of information in daily magazines (Novosti, Jutarnji list). The publishing of the magazine Yugoslavia: Yugoslav tourism, whose recognizable and modern visual identity was defined by Hans Wagula, also played a significant role in popularizing various aspects of tourism (Magaš Bilandžić 2016; Župančić \& Puljić 2016). Tourist propaganda in the Kingdom of Yugoslavia began to experience its rise during the 1930s, when many solutions by foreign and domestic artists were created. In addition to successful posters, brochures designed by Hanns Wagula and other artists of the time, individual posters and effective advertising campaigns were created for various tourist destinations (cities, regions and natural beauties), accommodation or travel, and contributed to the popularization of excursions and ski tourism, luxury multi-day cruises in the Mediterranean and other forms of vacations. In doing so, they applied the usual formula of tourist posters and, like Hanns Wagula, used a vertical format. Thus, Yugoslavia was depicted on tourist posters as a land of sun, sea, winter sports, a hospitable country, a country of friends and the like (Sudar 1971).

Extensive sections were dedicated to tourism and the tourism offer. Photo reports were published from tourist centers on the pages of popular illustrated magazines (Svijet). The Split Association for the Promotion of Tourism played a prominent role in promoting tourism and modern graphic design, and in the late 1920s and during the 1930s it regularly hired the Austrian Hans Wagula from Graz to design propaganda materials.

The Split Association especially stood out in the production of various propaganda materials and advocated "that all publications, especially posters of ours and all other institutions interested in tourism (Putnik, Jadranska Plovidba, Dubrovačka Plovidba, Aeroput, etc.), be at the highest artistic height" which is why they were often "entrusted with works of this kind, for which purpose they knew how to hire the best and most recognized artists in Europe."

Various Putnik activities such as publishing quality multilingual brochures, largeformat photo exhibitions with motifs of natural and cultural sights of Yugoslavia that were available in many world destinations, such as Leipzig, Dresden, London, Dusseldorf, Berlin, Paris, Cote d'Azur, Barcelona, Prague, Bratislava, Zurich, The Hague, Utrecht, Brussels, Warsaw, Poznan, Lvov, Thessaloniki, Izmir, New York, Milan, Bari, have influenced the increase in tourist demand of foreign and domestic tourists, but also to achieve excellent results in the field of domestic and foreign tourism. During this period, the employees of Putnik hired famous artists of that time to make posters and placards important graphic means for advertising (Krajčević 1988). 

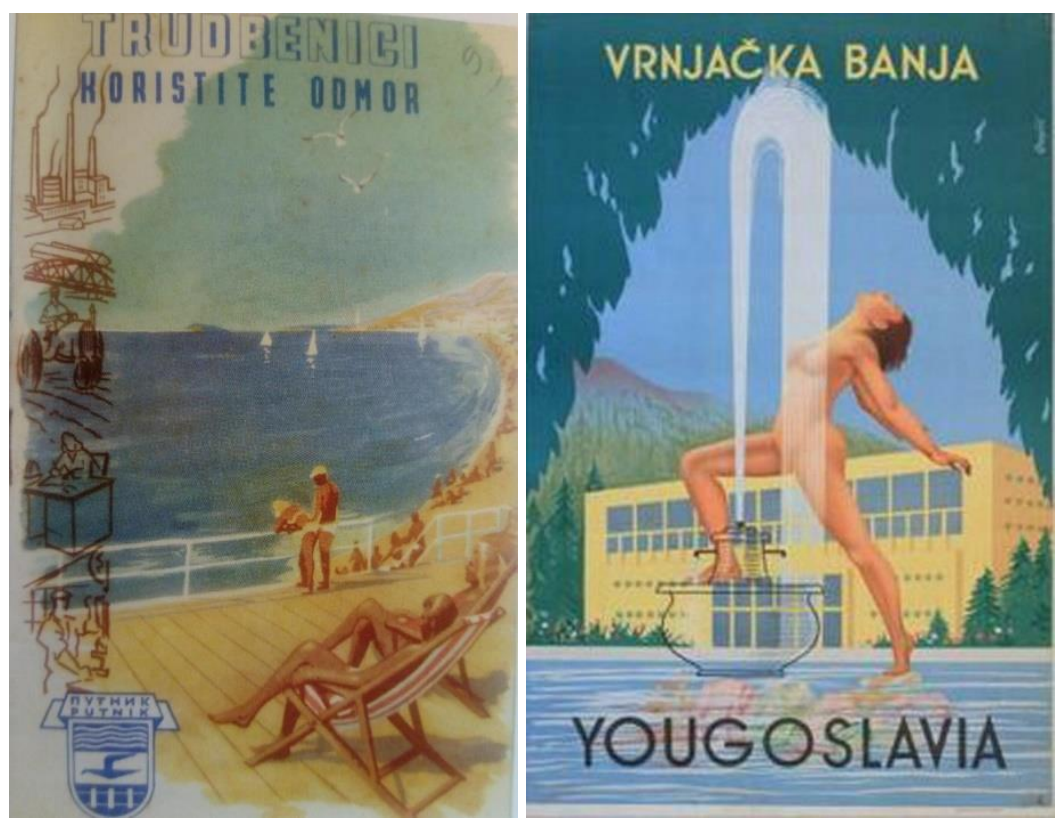

Source: Croatian Museum of Tourism, Opatija, inv. number 1173

Apart from Putnik, the Zagreb Fair also played a significant role in the development of tourist propaganda and the promotion of tourism in the interwar period, whose rules emphasized that the improvement of "foreign traffic" was followed by Radnička novina, an interesting example of propaganda conducted by the Atlas travel agency. Every Friday, on the same page of Zagreb's Večernji list, commercial messages were published (Vukonić 1973, 62).

In the 1970s, tourism developed on the Adriatic coast and tourism in general emerged as an economic branch in Croatia. At that time, the success of tourism was measured through three elements - the capacity, overnight stays and visitors. With the advancement of all three elements, tourist traffic and the construction of infrastructure increased, with the help of which Croatia created the preconditions to be a competitor to European and world tourism (Puljić \& Župančić 2017).

One of the features of tourist trips in Yugoslavia was the appearance of the first cars in the eighties, and owning a car became the rule and requirement. The cult Yugoslav "tin pets" - the Zastava 750, Zastava 101, and Yugo (fića, stojadin, and jugo - in Serbian), which were the most affordable in terms of price, were produced. Despite this, other brands were more popular among the population due to their higher quality, such as Renault or Škoda (Tomić 2013).

Although people then aspired to buy more luxurious cars, "the status of the Fića as a car that democratized the car industry by making it affordable became a car available to the masses of lower purchasing power, and its appearance on the Yugoslav market, according to Blaž Davidović, marked a symbolic beginning of consumer society" (Tomić 2013, 242, author's translation). This accessibility made it an integral part of Yugoslav popular culture and a symbol of that period. Although numerous cars of various brands 
and models were driven on Yugoslav roads, the Fića still left the biggest mark. It was a symbol of the rise of the Yugoslav economy, the golden age of socialism and, at the very end, the economic crisis and indebtedness of the state when driving was conditioned by the odd-even system (Tomić 2013, 244).

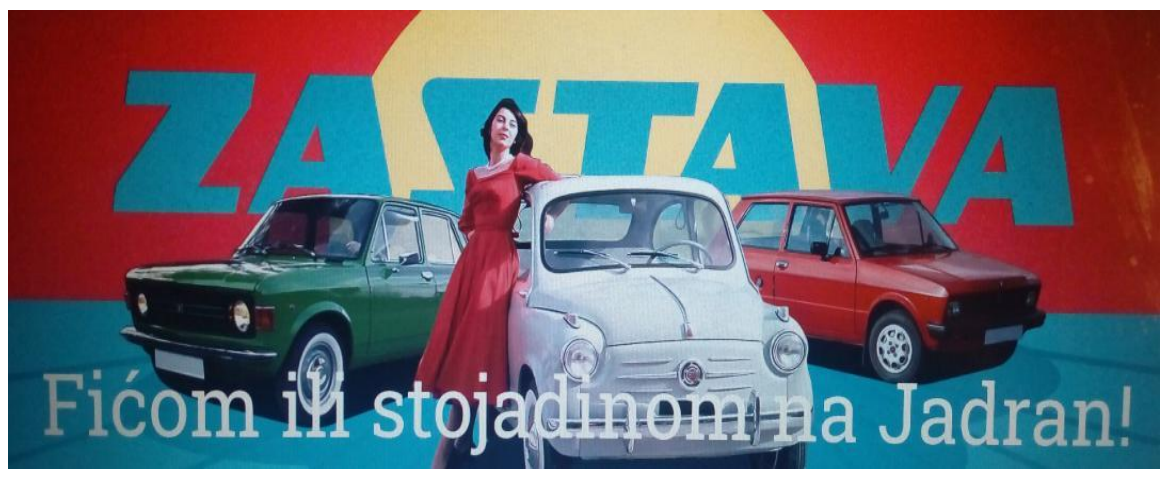

Source: http://modernizurnal.com/

\section{TOURIST PROPAGANDA IN YUGOSLAVIA}

Tourist posters and advertisements as forms of visual communication set specific tasks for graphic designers that distinguished them from other forms of advertising, and it was desirable that they contain the basic arguments used in tourist propaganda: technical and commercial, to indicate pleasant events, services and the appearance of the country. That is, their messages were focused on feelings and fantasies.

However, the period of crisis between the two wars had an adverse effect on tourism and travel. That is why certain messages appeared in the media: "Let's buy domestic" and "Leave money in your country", in order to discourage the local population from traveling abroad and to encourage them to spend the summer in Yugoslavia (Krejić \& Milićević 2018). In the interwar period, tourist posters were primarily intended for the international market, and for the upper bourgeoisie who could afford to visit spas, baths and other popular destinations. The poster was supposed to be simple, effective and with minimal resources to fulfill two key tasks - to quickly attract the attention and intrigue of a potential tourist, and to adequately present the country or tourist destination it advertised. Posters, as the most important form of tourist propaganda, received the most attention, and the role of attractively designed brochures was significant, which provided potential tourists with detailed information about individual places, hotel offers, various sports and cultural activities (Magaš Bilandžić 2016). The posters announcing events such as Labor Day celebrations, May $1^{\text {st }}$, and Youth Day, May $25^{\text {th }}$, had strong messages and were undoubtedly dominant, and thus require special study. These posters, apart from promotional, also had strong political messages (Vučetić 2011).

As tourism is always the first to be hit by wars, epidemics, natural disasters, which have a very unfavorable effect on its development and tourist movements, so it was during the last years of Tito's life. The economic crisis began to be felt much more strongly during 1984. The newspapers carefully reported on the fall in the standard of 
living, the crisis and the difficult life of the workers, the attempts to maintain the previous struggle and the habits of going on vacation. The headlines and slogans that were dominant in the newspapers at the time are "Those who have money bathe in the sea, and those who do not have money bathe at home in the washbowl" (Radničke novine 1984, author's translation). Or, "The working class is resting, while the blue Adriatic Sea ripples." The verses mocked a typical summer vacation marked by crowded buses, planes and trains, overbooked accommodation facilities, high prices, visits to relatives and ten days of leisure and sunbathing, followed by a return to new work victories (Duda 2013).

Advertising simply does not allow an unbalanced man to calm down at leisure and get out of the hectic pace of production-consumption, constantly forcing him to superficial mobility, whether persuading him to buy an item or a fast tourist trip that is spent on collecting as many shots and souvenirs as possible, as testimony that something had been seen and experienced (Martinić 1974).

\section{CONCLUSION}

The tourism of Yugoslavia cannot be singled out and observed separately, but must be understood in the context of the social, economic and political events of that time. The development of tourism in Yugoslavia experienced its mass character, thanks to the creation of infrastructure in different parts of the country at that time, especially on the Adriatic. The construction of roads, hotels, spa complexes, and the use of various means of transport, mostly concentrated in the coastal areas of the Adriatic Sea (especially Croatian islands), were just some of the positive effects they had on the popularization of tourist movements. However, the most important event for the development of tourism and the initiation of primarily the local population to travel is to give workers the opportunity to go on paid vacation, which until then they had been unable to. Under the 1974 constitution, a vacation became a constitutional right of every worker, and thus social tourism was created. Such decisions led to mass tourism in Yugoslavia for the first time, that is, to the possibility of many people from the continental parts of the country spending the summer at sea or in spas. The positive side of building infrastructure in the country of good natural and cultural resources has also influenced the arrival of an increasing number of foreign guests. On the other hand, communism as a totalitarian system promoted its ideology through tourism. The places of Tito's upbringing and partisan struggle, through which the cult of personality of Josip Broz was indirectly created, were an excellent basis for that.

Going on vacation is understood as an indispensable part of the standard of living and as a right of the entire population. In the system of social tourism, preferential prices for accommodation and transport, holiday pay are introduced, and workers', children's and youth resorts were established. Despite some objections, many workers were satisfied: "Workers' resorts are cheaper and people feel freer, because mostly acquaintances and friends are together. It's more enjoyable than with strangers. Besides, everything was organized, so I don't have to worry about anything. That's how a pleasant and really carefree vacation was spent." Many people traveled for the first time in the middle of the $20^{\text {th }}$ century and saw the sea, which was the main destination for summer vacations. Admiration for the sea was frequent in the media, which regularly reported on the holidays 
of workers, but also of local stars. "My favorite encounter is with our blue shores of the Adriatic, and it's most beautiful when I swim in it."

All this had a great influence on the creation of a culture of travel among the working class on the territory of Yugoslavia, which gave its contribution to the popularization of tourist movements, just like tourist propaganda.

\section{REFERENCES}

Autor nepoznat. "Letovanje u Jugoslaviji: Tito ih terao na more, a radnici mislilli da je prevara". Magazin Luftika 26. 07. 2019. (posećeno: 28. 06. 2020). Available at: https://luftika.rs/letovanje-u-jugoslaviji-tito.

Borman, Arthur. "Öffentliche und private Fremdenverkehrswebung”. Archiv für den Fremdenverkehr 3, 1 (1930/1).

Benić Penava, Marija, \& Đuro Matušić. „Razvoj smještajnih kapaciteta na dubrovačkom području između dva svjetska rata: polazište za razvoj suvremenog turizma“. Acta Turistica 24, 1 (2012): 61-85.

Crnjanski, Miloš. Belgrade. Bureau central de presse, 1936.

Duda, Igor. U potrazi za blagostanjem. O povijesti dokolice i potrošačkog društva u Hrvatskoj 1950-ih i 1960-ih. Zagreb: Srednja Europa, 2005.

Duda, Igor. Pronađeno blagostanje: Svakodnevni život i potrošačka kultura u Hrvatskoj 1970-ih i 1980-ih. Zagreb: Srednja Europa, 2010.

Duda, Igor. "Od radnika do turista. Prava, želje i stvarnost socijalnoga turizma u jugoslavenskome socijalizmu". U Sunčana strana Jugoslavije. Povijest turizma u socijalizmu, uredili Hannes Grandits i Karin Taylor, 55-87. Zagreb: Srednja Europa, 2013.

Fotić, Aleksandar. Privatni život u srpskim zemljama u osvit modernog doba. Beograd: Clio, 2005.

Garić, Dragana. Svet poslovnog reklamiranja između dva svetska rata. Novi Sad: Arhiv Vojvodine, 2010.

Grandits, Hannes, and Karin Taylor, eds. Yugoslavia's Sunny Side: A History of Tourism in Socialism (1950s1980s). Central European University Press, 2010.

Hall, Stuart. "Introduction to Media Studies at the Centre." In Culture, Media, Language, 114-119. Routledge, 2003.

Ilić, Kristina. „Plaćeni godišnji odmori u socijalističkoj Jugoslaviji (završni rad). Pula: Sveučilište Jurja Dobrile u Puli - Fakultet za interdisciplinarne, talijanske i kulturološke studije, 2018.

Istorijski arhiv Novog Sada, F.150/22742, 1940.

Крајчевић, Владан. Путник - акичонарско туристичко друштво: 75 година у туризму. Београд: „Путник“, 1998.

Krejić, Živana, and Snežana Milićević. „Nastanak putničko-agencijske delatnosti u Jugoslaviji kao pokretač razvoja kulture putovanja“. Kultura (2015): 39-51. doi: 10.5937/kultura1861039K.

Krejić, Živana, and Snežana Milićević. „Agricultural-industrial Exhibition in Pančevo 1905 as a Front of Contemporary Tourist Events “. Baština 49, 3 (2019): 191-202. doi: 10.5937/bastina1949191K.

Lazić, Svetlana. „Turizam u Beogradu između dva svetska rata kroz dokumente Istorijskog arhiva Beograda“. TIMS Acta 9 (2015): 37-47. doi: 10.5937/timsact9-7340.

Lemos, Andre. "Post-Mass Media Functions, Locative Media, and Informational Territories: New Ways of Thinking About Territory, Place, and Mobility in Contemporary Society". Space and Culture 13, 4 (2010): 403-420. doi: 10.1177/1206331210374144.

Magaš Bilandžić, Lovorka. „Hanns Wagula i turistički plakat u Hrvatskoj između dvaju svjetskih ratova“. Radovi Instituta za povijest umjetnosti 40 (2016): 183-195.

Malović, Gojko. Saobraćajne veze u Kraljevini Jugoslaviji: 1918-1941. Beograd, 2013.

Martinić, Tena. „Ideologija reklame.“ Politička misao 1, 3 (1974): 118-125.

McLuhan, Marshall. "The medium is the message". In Understanding Media: The Extensions of Man. London: Routledge, 1964.

Meynaudu, Jeanu. Les consommateurs et le pouvoir. Lausanne, 1964.

Mitrović, Borislav, prir. $O+P+P$ : Priručnik za upravljanje propagandom. Beograd: autorsko izdanje, 1988.

Otić, Ljubica, Veselinka Marković i Mirko Grlica. Sve je samo reklama: segmetni iz istorije reklame u Vojvodini do 1941. godine. Novi Sad: Muzej Vojvodine, 2012.

Pilar, Loris. Plaćeni odmor i masovni turizma u XX stoljeću (završni rad). Pula: Sveučilište Jurja Dobrile u Puli Odjel za interdisciplinarne, talijanske i kulturološke studije, 2016.

Popescu, Carmen. „A Disenchanted World? A Review of Holidays After the Fall: Seaside Architecture and Urbanism in Bulgaria and Croatia“. Architectural Histories 3, 1 (2015): 6. 
Popović, Milkica i Agneš Ozer. Ala smo se naodmarali... Omiljena mesta na kojima su se Vojvođani odmarali krajem XIX i početkom XX veka. Novi Sad: Muzej Vojvodine, 2015.

Periša, Antonija. Glazba i pop kultura 80-ih u Jugoslaviji (završni rad). Osijek: Sveučilište Josipa Jurja Strossmayera u Osijeku, Akademija za umjetnost i kulturu u Osijeku, 2018.

Puljić, M. i Katarina-Kaja Župančić. Turizam u Jugoslaviji 1970-ih. Zagreb: Hrvatsko katoličko sveučilište, 2017.

Radničke novine, 9. April, 1984.

Sorlin, Pierre. „Mass Media”, 1994.

Statistical Office of the Republic of Serbia. Statistički godišnjci 1960 i 1986. Retreived from https://www.stat.gov. rs/sr/publikacije (visited on 10. 05. 2020).

Rusac, Nikolina. Pazinka: Kulturnoantroploški i muzeološki pristupi tematizaciji industijskog nasleđa socijalizma. Zagreb: Sveučilište u Zagrebu - Filozofski fakultet, 2014

Sezgin, Erkan, and Medet Yolal. „Golden Age of Mass Tourism: Its History and Development“. In Visions for Global Tourism Industry - Creating and Sustaining Competitive Strategies, edited by Murat Kasimoglu, 7390. InTech, 2012

Sudar, Josip. Ekonomska propaganda. Zagreb: Informator, 1971.

Stanković, Stevan M. „Savremeni problemi domaćeg i inostranog turizma u Jugoslaviji“. Dela 6 (1989): 276 -283.

Swarbrooke, John, and Susan Horner. Consumer Behaviour in Tourism. Routledge, 2007.

Tomić, Antonia. „Generacija sretnika- svakodnevica u kulturi i književnosti 70-ih i 80-ih godina 20. stoljeća“. Zagreb: Filozofski fakultet u Zagrebu, 2013.

Škara, Matija. Razvoj i tijek turizma Hrvatske od kraja Drugog svjetskog rata do 1990. godine (završni rad). Zadar: Sveučilište u Zadru - Odjel za turizam i komunikacijske znanosti, 2016.

Šuràn, Fulvio. Slobodno vrijeme, putovanje i turizam: sociološki pristup. Pula: Sveučilište Jurja Dobrile, 2016.

Vukonić, Boris. Turistička propaganda. Zagreb: Školska knjiga, 1973.

Vukonić, Boris. Povijest hrvatskog turizma. Zagreb: Prometej, 2005.

Župančić, Katarina Kaja, \& Mihael Puljić. „Turizam u Jugoslaviji 1970-ih“. Rostra: časopis studenata povijesti Sveučilišta u Zadru 8, 8 (2017): 233-246.

\section{KULTURA PUTOVANJA U JUGOSLAVIJI: ANALIZA TURISTIČKE PROPAGANDE}

U radu je dat pregled jugoslovenske turističke propaganda koja se odnosila pre svega na primorje, ali i začetke razvoja masovnog turizma radničke klase. Analizirani su do sada istraženi arhivski dokumenti u oblasti istorije razvoja turizma i naučni radovi koji se odnose na kulturu putovanja u Jugoslaviji. Istraživanje ima cilj da sagleda $i$ analizira turističku propagandu sa sociološkog aspekta u Jugoslaviji tokom 20. veka, kada je jedna od glavnih karakterisika turizma bila njegova masovna pojava. Uprkos razvoju privrede i usponu razvoja turizma, građani Jugoslavije su imali kratak godišnji odmor, koji su realizovali odlascima na more, u banje, na planine, $i$ to najčešce u sopstvenoj organizaciji, a najmanje su koristili usluge turističkih agencija. Brojni katalozi, brošure, oglasi u novinama predstavljaju važne segmente turističke propagande i putokaz domaćim turistima ka popularnim destinacijama. Težak položaj radnika koji su se borili da sačuvaju ideju o odlasku na godišnje odmore bio je vidljiv i kroz neke od slogana o letovanju: „Ko ima para kupa se u moru, a ko nema kući u lavoru“. Životni standard ljudi diktirao je odluke o putovanjima, a tek 1964. godine donošena je odluka da godišnjih odmor traje šest dana i da bude plaćen, čime turizam dobija epitet socijalnog turizma. Rezultati istraživanja pružaju uvid u svakodnevni život stanovnika Jugoslavije, njihove mogućnosti za odlazak na godišnji odmor, turističkoj propagandi, koja je i u svojim začecima bila veoma raskošna, ali i najčešćim destinacijama na koje se putovalo.

Ključne reči: turizam, putovanja, kultura, radnici, svakodnevni život, Jugoslavija. 